newborn. American Journal of Diseases of Children, 106, 137-146.

Nickman, S. L., Buckler, J. M., and Weiner, C. B. (1968). Further experiences with water intoxication. Pediatrics, 41, 149-151.

Pickering, C. K., and Hugan, G. R. (1971). Voluntary water intoxication in a normal child. Journal of Pediatrics, 78, 316-318.

Rutter, N., and Smales, C. R. (1977). Role of routine investi- gations in children presenting with their first febrile convulsions. Archives of Disease in Childhood, 52, 188-191.

Wynn, V., and Rob, C. G. (1954). Water intoxication: differential diagnosis of the hypotonic syndromes. Lancet, $1,587-594$.

Correspondence to Dr A. Etzioni, Department of Paediatrics A, Rambam University Hospital, Aba Khoushy School of Medicine, Rambam Medical Center, Haifa, Israel.

\title{
Copper deficiency in a low birthweight infant
}

\author{
P. YUEN, H. J. LIN, AND J. H. HUTCHISON \\ University Departments of Paediatrics and Pathology, Queen Mary Hospital, Hong Kong
}

SUMMARY Copper deficiency is reported in an infant of very low birthweight. It was characterised by extensive bone changes, severe neutropenia, and hypocupraemia. These manifestations could have been missed but for an intercurrent pneumonia which led to an $x$-ray of the chest.

Low birthweight infants go into negative nitrogen balance from birth and there may also be substantial losses of trace elements (Shaw, 1973). Absorption of nutrients may also be poor. It is surprising, therefore, that there have been so few reports of copper deficiency in low birthweight infants (Al-Rashid and Spangler, 1971; Griscom et al., 1971; Ashkenazi et al., 1973; Sann et al., 1978) and it is possible that some cases go unrecognised.

\section{Case report}

A Chinese baby, son of a 28-year unmarried hostess at a dance hall, was born spontaneously in the hospital casualty department at 28 weeks' gestation on 24 August 1977. Birthweight $970 \mathrm{~g}$; length $39 \mathrm{~cm}$; head circumference $26 \mathrm{~cm}$. The clinical and radiological features of idiopathic RDS rapidly developed. The infant was nursed in an incubator in $60 \% \mathrm{O}_{2}$, an umbilical artery was catheterised for blood-gas studies, and IV $10 \%$ dextrose was given at a rate of $3 \mathrm{ml} /$ hour. Apnoeic attacks necessitated the use of CPAP on 25 August and IV aminophylline was given $1.5 \mathrm{mg}$ six-hourly. $\mathrm{PaO}_{2}$ varied between 47 and 115 mmHg $(6 \cdot 2$ and $15 \cdot 3 \mathrm{kPa})$. Metabolic acidosis was corrected with sodium bicarbonate. Parenteral feeding with Aminofusin, dextrose, and Intralipid was started on 26 August. CPAP was stopped on 30 August, and the ambient $\mathrm{O}_{2}$ concentration gradually reduced. An attempt at nasogastric feeding on 31 August produced blood from the gastric aspirate and $\mathrm{Hb}$ fell to $10 \mathrm{~g} / \mathrm{dl}$, and then rose to 15 $\mathrm{g} / \mathrm{dl}$ after a transfusion of $25 \mathrm{ml}$ fresh blood. Parenteral feeding was discontinued on 20 September when the infant's full caloric requirements were being given in the form of Nan (Nestlé) by nasogastric tube. $\mathrm{Hb}$ was $11.5 \mathrm{~g} / \mathrm{dl}$. On 1 October proprietary ferrous sulphate and multivitamin preparations were started orally. However, on 4 October $\mathrm{Hb}$ was $7.6 \mathrm{~g} / \mathrm{dl}$; WBC $45.1 \times 10^{9} / 1$; neutrophils $31 \%$; lymphocytes $69 \%$; platelets $645 \times$ $10^{9} / 1$; reticulocytes $4 \cdot 8 \%$. Films showed 12 nucleated $\mathrm{RBC} / 100$ WBC. On the suspicion of vitamin $\mathrm{E}$ deficiency (Willoughby, 1977) IM tocopherol $100 \mathrm{mg}$ daily was given for 4 days. Unfortunately, the infant developed bronchopneumonia (treated with IV gentamicin and ampicillin) and on 17 October $\mathrm{Hb}$ was $6.3 \mathrm{~g} / \mathrm{dl}$; reticulocytes $8.7 \%$. A further 4-day course of tocopherol was given and on 10 November $\mathrm{Hb}$ was $11.3 \mathrm{~g} / \mathrm{dl}$; reticulocytes $2 \cdot 6 \%$. The infant was discharged home on 22 November on Nan $75 \mathrm{ml}$ three-hourly $\times 8$, plus iron and vitamin supplements. Weight $2 \cdot 33 \mathrm{~kg}$; head circumference $32.5 \mathrm{~cm}$.

The baby was readmitted on 13 December extremely ill and convulsing with bronchopneumonia. Weight $3.0 \mathrm{~kg}$. Respirations $60 / \mathrm{min}$. Blood $\mathrm{pH}$ $7.03 ; \mathrm{PaO}_{2} 73 \mathrm{mmHg}(9 \cdot 7 \mathrm{kPa}) ; \mathrm{PaCO}_{2} 94 \mathrm{mmHg}$ $(12.5 \mathrm{kPa})$; base excess-7.5 mmol/1. Serum Na 132 $\mathrm{mmol} / \mathrm{l} ; \mathrm{K} 5 \cdot 8 \mathrm{mmol} / 1 ; \mathrm{Ca} 2 \cdot 4 \mathrm{mmol} / 1(9.6 \mathrm{mg} /$ $100 \mathrm{ml}) ; \mathrm{P} 2.38 \mathrm{mmol} / 1(7.4 \mathrm{mg} / 100 \mathrm{ml}) ; \mathrm{Mg} 1 \cdot 0$ $\mathrm{mmol} / \mathrm{l}(2 \cdot 4 \mathrm{mg} / 100 \mathrm{ml})$. Hb $10 \cdot 2 \mathrm{~g} / \mathrm{dl}$; WBC $20 \cdot 3$ $\times 10^{9} / 1$; neutrophils $26 \%$; lymphocytes $67 \%$; monocytes $7 \%$; reticulocytes $4 \cdot 6 \%$. CSF normal. There was a good response to cephradine given IV combined with nursing in $40 \% \mathrm{O}_{2}$. However, a repeat chest $x$-ray on 21 December showed widening of the anterior rib ends, subperiosteal reaction, and fractures of the right 6 th, 7 th, and 8th ribs and of the left 5th, 6th, 7th, and 8th ribs.

A skeletal survey showed diaphyseal subperiosteal 
new bone formation with cupping and flaring of the metaphyses and severe osteoporosis. There were fractures of the lower ends of the left radius and right ulna (Figure). Repeat blood tests showed serum Ca $2 \cdot 1 \mathrm{mmol} / 1(8 \cdot 4 \mathrm{mg} / 100 \mathrm{ml}) ; \mathrm{P} 2.94 \mathrm{mmol} / 1$ ( $9 \cdot 1$ $\mathrm{mg} / 100 \mathrm{ml}$ ); alkaline phosphatase $610 \mu \mathrm{mol} / \mathrm{min}$ per litre (Chinese adults 35-115). VDRL negative. On 19 January 1978 serum Cu was $0.7 \mu \mathrm{mol} / 1(4.5 \mathrm{mg} /$ $100 \mathrm{ml}$ ) (normal 11-25), and serum caeruloplasmin was barely detectable (normal 62-108 $\mu \mathrm{mol} / \mathrm{min}$ per litre). $\mathrm{Hb}$ was $11.9 \mathrm{~g} / \mathrm{dl}$; WBC $7.3 \times 10^{9} / 1$; neutrophils $1 \%$; lymphocytes $90 \%$; monocytes $8 \%$; eosinophils $1 \%$; serum Fe $8 \mu \mathrm{mol} / \mathrm{l}(44 \cdot 7 \mu \mathrm{g} / 100 \mathrm{ml})$; TIBC $51 \mu \mathrm{mol} / 1(285 \mu \mathrm{g} / 100 \mathrm{ml})$. On 25 February, when the infant had been on cereals in addition to the milk formula for 52 days, serum $\mathrm{Cu}$ was 2.0 $\mu \mathrm{mol} / 1(12 \cdot 7 \mu \mathrm{g} / 100 \mathrm{ml})$; caeruloplasmin $10 \mu \mathrm{mol} /$ min per litre; plasma ascorbate $94.2 \mu \mathrm{mol} / 1(1.6$ $\mathrm{mg} / 100 \mathrm{ml}) ;$ serum zinc $9 \cdot 2 \mu \mathrm{mol} / \mathrm{l}(60 \cdot 1 \mu \mathrm{g} / 100 \mathrm{ml})$ (Chinese adult range $15 \cdot 7 \pm 2.75 \mu \mathrm{mol} / \mathrm{l}) . X$-rays taken on 1 March already showed early healing of bone lesions but the infant was started on 0.6 $\mathrm{ml}$ of $0.5 \%$ copper sulphate solution daily. On 14 March serum Cu was $10 \mu \mathrm{mol} / 1(63.7 \mu \mathrm{g} / 100 \mathrm{ml})$;

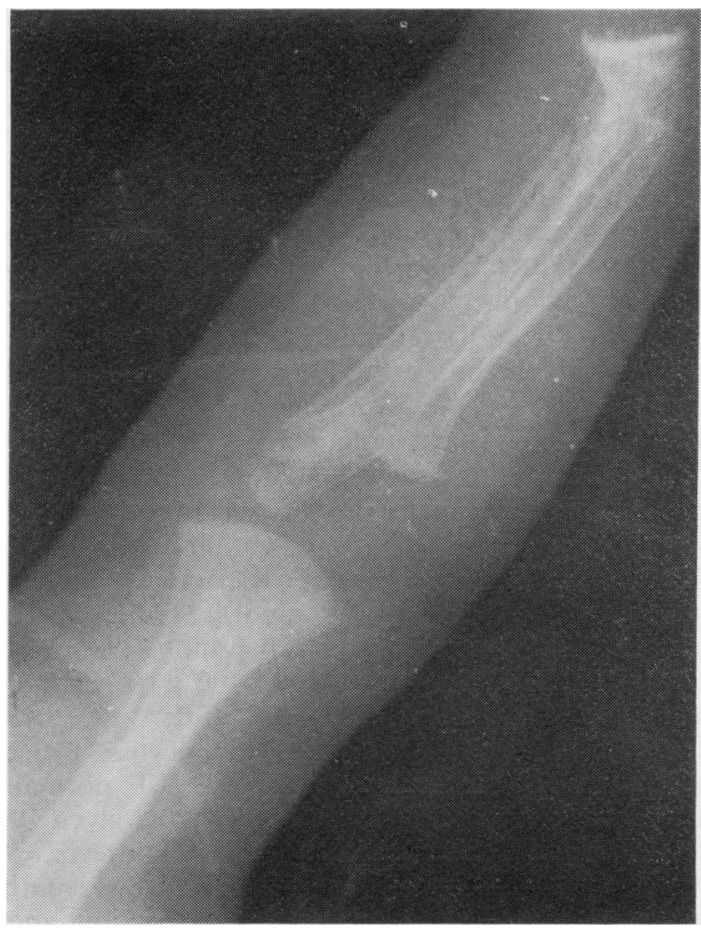

Figure $X$-ray' at age 4 months showing subperiosteal reaction, osteoporosis, flaring and cupping of metaphyses, and fracture of lower end of radius. caeruloplasmin $43 \mu \mathrm{mol} / \mathrm{min}$ per litre. $\mathrm{Hb}$ was $12 \cdot 4$ $\mathrm{g} / \mathrm{dl}$; WBC $15.6 \times 10^{9} / 1$; neutrophils $47 \%$; lymphocytes $51 \%$; monocytes $1 \%$; eosinophils $1 \%$; reticulocytes $2 \cdot 6 \%$; platelets $339 \times 10^{9} / 1$. Copper supplements were stopped on 22 March when serum $\mathrm{Cu}$ was $22 \mu \mathrm{mol} / \mathrm{l}(140 \mu \mathrm{g} / 100 \mathrm{ml})$; caeruloplasmin $65 \mu \mathrm{mol} / \mathrm{min}$ per litre. $X$-ray on 29 March showed almost complete healing of bone lesions apart from residual subperiosteal reaction in both femora, although bone-age was only 3 months. The infant went home on 18 May, weight $4.8 \mathrm{~kg}$, on feeds of Cow and Gate Babymilk Plus and mixed feeding. He was still unable to sit unsupported or to roll over from the supine to the prone posture, but in the prone position he could lift his head and chest off the table and he made attempts to grasp objects. Unfortunately his home environment is unlikely to encourage much stimulation.

\section{Discussion}

The diagnosis of copper deficiency in this case is based upon the characteristic bone changes, severe neutropenia, and extremely low serum copper and caeruloplasmin levels. Anaemia is common in copper deficiency but was absent in our patient. When the bone changes were first discovered our initial suspicion was rickets. Indeed, this has been reported in association with copper deficiency in a low birthweight infant (Sann et al., 1978). However, the high serum phosphate level made this diagnosis unlikely, particularly as the infant had been receiving a calculated daily intake of at least $10 \mu \mathrm{g}$ vitamin $\mathrm{D}$. We have not seen such severe subperiosteal new bone formation in rickets but measurements of plasma $25-\mathrm{OHD}_{3}$ or iPTH were not available to us. There was no evidence of nonaccidental injury and the long bone changes were incompatible with this diagnosis. If this infant had not been readmitted to hospital with pneumonia the diagnosis would have been missed because even after finding extensive bone changes on $x$-rays there was no clinically obvious beading of the ribs or epiphyseal enlargement, and it is probable that spontaneous healing would have followed the introduction of mixed feeding. On the other hand, a neutropenia of $1 \%$ must have greatly reduced the infant's resistance to infection.

Copper deficiency has been reported in older infants after prolonged total parenteral nutrition (Karpel and Peden, 1972; Heller et al., 1978) as well as in very low birthweight infants. In our patient parenteral nutrition was only total for 6 out of 26 days, and the extreme prematurity and low birthweight were likely to be more important factors leading to copper deficiency. 
We thank Dr L. Y. Y. Fong for the serum zinc analysis.

\section{References}

Al-Rashid, R. A., and Spangler, J. (1971). Neonatal copper deficiency. New England Journal of Medicine, 285, 841-843.

Ashkenazi, A., Levin, S., Djaldetti, M., Fishel, E., and Benvenisti, D. (1973). The syndrome of neonatal copper deficiency. Pediatrics, 52, 525-533.

Griscom, N. T., Craig, J. N., and Neuhauser, E. B. D. (1971). Systemic bone disease developing in small premature infants. Pediatrics, 48, 883-895.

Heller, R. M., Kirchner, S. G., O'Neill, J. A., Jr, Hough, A. J., Jr, Howard, L., Kramer, S. S., and Green, H. L. (1978). Skeletal changes of copper deficiency in infants receiving prolonged total parenteral nutrition. Journal of Pediatrics, 92, 947-949.

Karpel, J. T., and Peden, V. H. (1972). Copper deficiency in long-term parenteral nutrition. Journal of Pediatrics, 80, 32-36.

Sann, L., David, L., Galy, G., and Romand-Monier, M. (1978). Copper deficiency and hypocalcaemic rickets in a small-for-date infant. Acta paediatrica Scandinavica, 67, 303-307.

Shaw, J. C. L. (1973). Parenteral nutrition in the management of sick low birthweight infants. Pediatric Clinics of North America, 20, 333-358.

Willoughby, M. L. N. (1977). Paediatric Haematology, p. 149, Churchill-Livingstone: Edinburgh.

Correspondence to Professor J. H. Hutchison, Queen Mary Hospital, Department of Paediatrics, Hong Kong.

\title{
Pulmonary candidiasis in cystic fibrosis
}

\author{
B. M. JENNER, L. I. LANDAU, AND P. D. PHELAN
}

Royal Children's Hospital, Melbourne, Australia

SUMMARY A child with cystic fibrosis and asthma developed pulmonary candidiasis. Predisposing factors in this patient were prolonged antibiotic therapy, high-dose corticosteroids, and intravenous catherisation. A diagnosis was made by lung puncture and confirmed by rapid response to 5 -fluorocytosine.

Pulmonary candidiasis is an invasion of viable lung tissue by Candida species. It has long been known that this occurs in patients with impaired host resistance-such as those with Hodgkin's disease or leukaemia, and those on cytotoxic therapy. In 1844 Bennett commented: 'it is indicative of great depression of the vital powers and impairment of the nutritive functions of the economy' (Winner and Hurley, 1966).

Candida colonisation is seen in the tracheobronchial tree of children with cystic fibrosis on long-term antibiotics. Pulmonary candidiasis, however, has not been reported in such children.

This is a report of a child with cystic fibrosis and asthma requiring corticosteroids, who developed pulmonary candidiasis and responded to treatment with 5-fluorocytosine.

\section{Case report}

A $6 \frac{1}{2}$-year-old girl had cystic fibrosis diagnosed in the first year of life and associated bronchial asthma. She was initially well maintained on standard antibiotic and physical therapy for cystic fibrosis lung disease, with intermittent bronchodilator treatment for the asthma.

At age 5 years she required continuous bronchodilators and, subsequently, three intermittent courses of corticosteroids to control the wheeze. At 6 years more prolonged courses of high-dose prednisolone were necessary to control quite severe airways obstruction but these were reduced to a maintenance dose of $4 \mathrm{mg}$ daily. During a course of high-dose prednisolone for an acute exacerbation of airways obstruction she became increasingly lethargic, lost weight, and developed a fever which reached $39^{\circ} \mathrm{C}$ daily. She developed rapid shallow breathing with fine inspiratory crepitations. Chest $x$-rays showed increased reticulonodular markings (Figure).

Intravenous cloxacillin and gentamicin, and later chloramphenicol and carbenicillin, were given for nearly 4 weeks without response. On several occasions sputum cultures grew Escherichia coli, Streptococcus species, Haemophilus influenzae, and Achromobacter species, but moderate to profuse growth of Candida species, not $C$. albicans, was always present. Multiple blood cultures were negative. Immune function tests were normal. Tuberculosis, autoimmune disease, and sepsis elsewhere were excluded.

A lung puncture was performed with instillation of $2 \mathrm{ml}$ saline into the lung and aspiration of alveolar fluid. This fluid was smeared and cultured. A pure growth of Candida species, not $C$. albicans, was obtained.

She was started on 5-flurocytosine orally; within 